Ishchenko I., Savenko A., Chupryna N., Kovalova M.

\title{
ANALYSIS OF SMART HOURS AND FITNESS TRACKERS IN THE MARKET OF UKRAINE
}

\author{
Ukrainian State University of Chemical Technology, Dnipro, Ukraine
}

\begin{abstract}
The article analyzed the goods of smart watches and fitness trackers, in order to find out how much their manufactured products are in demand in the modern market, as well as which store is better to open (online or regular) and whether it is profitable to open a store with a product of fitness trackers and smart hours The main problem on the topic is a small scientific research in this field of activity, respectively, the article has a generalized new material that takes into account all aspects of the real marketing situation. When studying smart watches and fitness trackers, a theoretical review of macromarketing and micromarketing environments was conducted. As a result of the obtained data, an analysis was formed, which took into account the advantages and disadvantages of the smart watch market and fitness trackers, based on the selection and analysis of factors of the macromarketing environment, namely such factors as political, economic, demographic, scientific and technical, and socio-cultural. Particular attention is paid to the study of the competitive environment, where they considered the main competitors of the start-up enterprise selling fitness trackers and smart watches, namely, such trading platforms as Eldorado, Comfy, AliExpress, Rosette, Foxtrot, «Citrus», «Allo». On the basis of the data studied, an analysis was made of the number of models of each competitor presented to determine the product range. The analysis of suppliers, which is aimed at identifying those aspects in the activities of entities supplying the organization with various raw materials, semi-finished products, energy, information, finance, etc., on which the effectiveness of the organization, cost and quality of the product produced by the organization depends, is carried out. The article analyzes each product among the submitted competitors to calculate the average price in order to see the difference in the prices of products manufactured in China, EU countries and the USA. These indicators predetermine actions in the selection of suppliers and intermediaries of products. Based on the study of the competitiveness of this market segment, the basic strategy of M. Porter was proposed, which provides for the specialization of the company's activities in a narrow segment of consumers and gaining leadership in this segment. The goal of the strategy is to satisfy the needs of the chosen target segment better than the competitors. To determine the attitude of society to the industry in this market segment, a consumer survey was conducted in which 100 respondents took part, of which $51 \%$ of respondents are female and $49 \%$ are male in order to find out which characteristics of smart watches and fitness trackers suit or not satisfied with consumers, as well as the problems of modern wearable gadgets. By integrating the information studied, the stability of this market segment and the possibilities for opening your business are determined. Suggested recommendations for opening a store in the field of smart watches and fitness trackers.
\end{abstract}

Keywords: potential consumer, market research, analysis of competitors, price segment, competitive edge.

DOI: $10.32434 / 2415-3974-2019-9-1-136-141$

(C) Ishchenko I., Savenko A., Chupryna N., Kovalova M., 2019 


\section{Statement of the problem}

In connection with the rapid growth of technology, at the moment people who use various gadgets, all pay less attention to little-known brands and give greater preference to technology that has a brand promoted than technological characteristics or price. Therefore, we hypothesize that opening a new store selling fitness trackers and smart watches in Ukraine is a very risky business and will not bring the expected income.

The relevance of this study lies in the fashion of 2018 on "Healthy lifestyle" and "Planning your time".

The analysis of researches and publications

Analysis of scientific approaches to marketing research involved in many foreign and Ukrainian scientists: E. Anokhin, V. Anokhin, Z. Kasatova, J. Martynov, S. Bozhuk, L. Kovalik, N. Kameneva, V. Polyakov, B. Gerasimov, N. Mozgov, etc.

\section{The purpose of this article}

This article justifies the demand for smart watches and fitness trackers, in order to find out how much their manufactured products are in demand in the modern market, as well as which store is better to open (online or regular) and whether it is profitable to open a store with a product of fitness trackers and smart watch.

\section{Exposition of basic material}

Let us analyze the problems and opportunities of the market of smart watches and fitness trackers based on the selection and analysis of factors of the macro marketing environment and determine how they affect certain factors of the macro environment - create problems or present opportunities.

From the political factors of the macromarketing environment, we can conclude that the problems of the opening store are: political stability in the country, product certification, the state of consumer protection legislation (our company cannot influence the solution of these problems); the likelihood of the development of military actions in the country (this problem can be partially solved by securing yourself and your property, first of all, with the help of insurance).

The advantages are much less: freedom of information and independence of the media (which is our tool for the implementation of ideas), the degree of protection of intellectual property and copyright law (the company cannot influence these factors, but gives confidence to the future of this business).

From the economic factors of the macromarketing environment, we can conclude that the problems are: the inflation rate in the country, the unemployment rate and the availability of credit (the company cannot influence these factors).

Such a criterion as currency regulation gives a slight advantage, but the company also can not affect this factor.

From the demographic factors of the macromarketing environment, the problems are: migration flows and trends and territorial distribution (the company cannot influence the solution of these problems).

A positive factor is the ethnic and religious structure of the population (Christianity prevails in Ukraine, which gives freedom of action, and allows the enterprise to realize its potential by expanding the segment of potential buyers).

Positive scientific and technical factors are: the acceleration of technical progress (the company can monitor daily innovations in the field of engineering and technology and expand its range); toughening the state quality control and product safety (the company cannot influence this factor); product renewal (allows the company to reduce the cost of products and provide a greater choice than its competitors); the direction and dynamics of investments in NTP (the company can not affect this factor, and can only follow the development of this market segment).

The problem is the environmental orientation of the NTP (the company can not affect this factor). Due to the fact that we are intermediaries, our type of activity does not affect the natural factors of the macro marketing environment.

From the socio-cultural factors of the macromarketing environment, we can conclude that the problem is: moral norms in society (an enterprise can only try to satisfy all the demands of consumers for a minimal fee).

Opportunities are: trends, fashion and cultural values $\dagger$ of the consumer (for an enterprise it is an opportunity to realize more positions of this type of goods); import preference (the company cannot influence this factor, as there is no domestic producer).

Of all the above factors, the most important are economic and socio-cultural. To a greater extent, an enterprise can influence economic factors, sociocultural and scientific-technical, and to a lesser extent political, demographic factors, and natural ones. Such a factor as a political enterprise cannot influence in any way.

The main competitors of the start-up enterprise are the shops and online stores of Eldorado, Comfy, AliExpress, Rosetka, Foxtrot, Citrus, Allo (table 1).

Analysis of the range of goods was made based on the analysis of secondary information. We analyzed the assortment of groups in the networks of shops and Internet sales (table 2).

After analyzing the number of models of smart watches and fitness trackers of competitors, we see that the largest choice is given on the online platform 
Analysis of competitors

\begin{tabular}{l|c|c|c|c|c|c|c}
\hline \multirow{2}{*}{ Factors } & \multicolumn{7}{c}{ Oт -3 до +3} \\
\cline { 2 - 8 } & Eldorado & Comfy & AliExpress & Rosetka & Foxtrot & Citrus & Allo \\
\hline Product range & +1 & +1 & +3 & +3 & -1 & +2 & +3 \\
\hline The price of the product & +1 & -2 & +2 & +1 & +1 & +1 & -2 \\
\hline Product quality & +2 & +2 & +1 & +2 & +2 & +2 & +2 \\
\hline
\end{tabular}

Table 2

Analysis of the depth of the range

\begin{tabular}{l|c|c|c|c|c|c|c}
\hline \multirow{2}{*}{ Product } & \multicolumn{7}{c}{ Количество моделей } \\
\cline { 2 - 8 } & Eldorado & Comfy & AliExpress & Rosetka & Foxtrot & Citrus & Allo \\
\hline Smart watch & 136 & 161 & 590648 & 2872 & 93 & 786 & 1372 \\
\hline Baby Smart Watch & 55 & 50 & 4445 & 688 & 2 & 27 & 60 \\
\hline Fitness trackers & 109 & 329 & 46302 & 799 & 49 & 2 & 166 \\
\hline
\end{tabular}

AliExpress and Rosetka, the smallest choice is provided in the Foxtrot store. Consequently, we can conclude that the Internet sites, allows you to provide a huge choice to the buyer, at minimal cost.

The analysis revealed that most smart watch models and fitness trackers are represented in online stores such as AliExpress and Rosetka. The least models of these gadgets are presented at the Foxtrot Store. The range of gadget data in stores Allo is a leading position among analogue technology supermarkets. However, Internet platforms allow a much wider range of products, which brings them to the top positions of the rating.

The next step in the analysis of competitors is to analyze the pricing policy of each of them. If the cost allows you to determine the minimum price level, the demand - the maximum, the analysis of competitor prices allows you to determine the prices within these limits, given the prices of competitors.

In this case, it is important not only to analyze prices, but also the structure of competitor prices. It should be noted that awareness on this issue automatically strengthens the position of the firm and provides an opportunity to find vulnerable positions of competitors.

For example, in order to analyze the structure of the production costs of their rivals, some manufacturers buy models of competitors and disassemble them on nodes and parts. The information obtained is used as a benchmark in determining the reserves of lowering costs and further reducing prices for their products.

The analysis of competitors' prices is carried out using price list prices, through surveys of buyers, and their account makes it possible to clearly position the product or service. The next step in determining the price is related to the choice of pricing method.

The analysis of market average prices for various models of smart watches and fitness trackers is given in Table 3. The data is collected from open sources of information: the price in shops and prices at various Internet sites.

Table 3

Analysis of the average market price of different models smart watches and fitness trackers

\begin{tabular}{l|c|c}
\hline \multicolumn{1}{c|}{ Product name } & $\begin{array}{c}\text { Average price, } \\
\$\end{array}$ & $\begin{array}{c}\text { Average price, } \\
\text { грн }\end{array}$ \\
\hline Apple Watch Series 3 & 399 & 11061.89 \\
\hline Garmin Fenix 5 & 599.99 & 16634.14 \\
\hline FitBit Ionic & 300 & 8317.21 \\
\hline Samsung Gear S3 & 349.99 & 9703.13 \\
\hline Sony SmartWatch 3 & 128 & 3548 \\
\hline Huawei Watch 2 & 179.99 & 4990.04 \\
\hline Asus ZenWatch 3 & 230 & 6376.52 \\
\hline LG Watch Style & 280 & 7762.73 \\
\hline Xiaomi Amazfit Pace & 100 & 2772.40 \\
\hline Tag Heuer Connected & 1500 & 45860.55 \\
\hline
\end{tabular}

After analyzing each product among the represented competitors. we derived 10 positions and calculated the average price in order to see the difference in the prices of products manufactured in China. EU countries and the USA (Figure).

Based on the evaluation of competitors. we. based on M. Porter's basic strategy. chose a concentration strategy that provides for the specialization of the company's activities in a narrow segment of consumers and gaining leadership in this segment. The goal of the strategy is to satisfy the needs of the chosen target segment better than the competitors.

The analysis of suppliers is aimed at identifying 


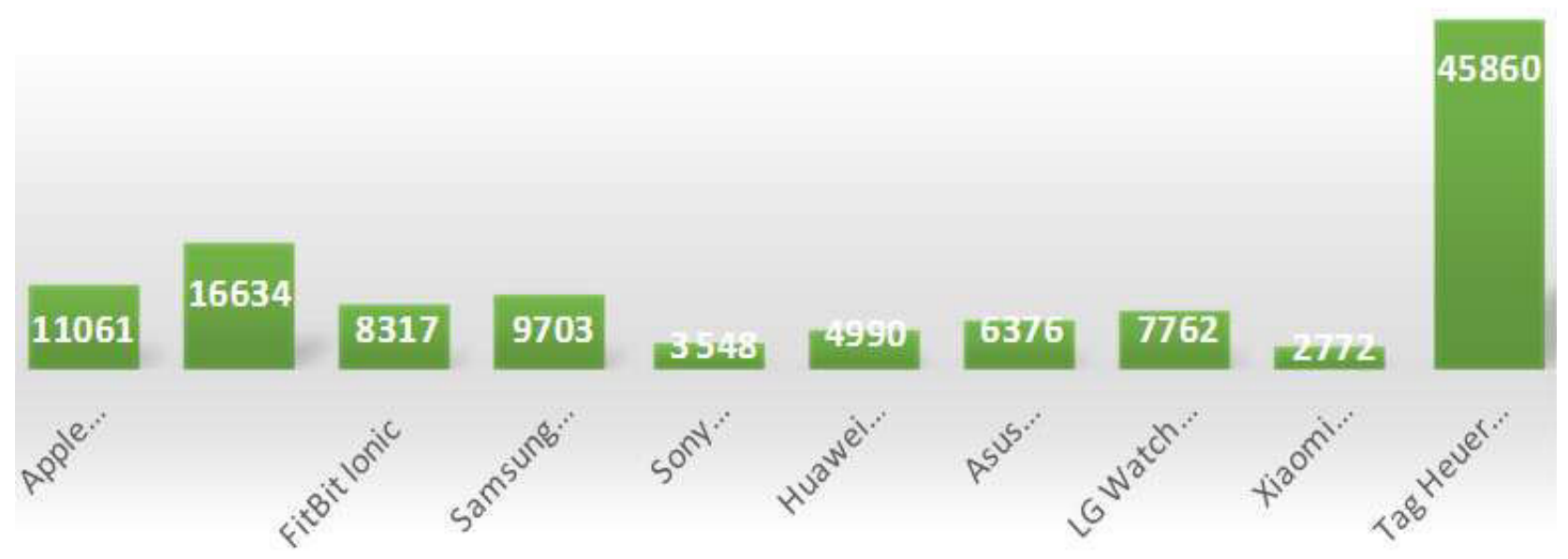

Average market price of models UAH

those aspects in the activities of entities supplying the organization with various raw materials, semifinished products, energy, information, finance, etc., on which the effectiveness of the organization. cost and quality of the product produced by the organization depend.

After analyzing the 5 products of smart watches most popular among our competitors, we see that our country is not a manufacturer of more than one brand, our country buys more models of smart watches from other countries. The most popular dealers in Ukraine are Foxtrot, Citrus, Hello, Comfy, Rosetka, i.e. our direct competitors. Basically everything is done and sold in Taiwan or in China itself. An exception is the proposed Tag Heuer Connected model. which is manufactured and sold in Switzerland.

A study conducted by us showed that many users of wearable devices - smart watches and fitness trackers - are disappointed in their gadgets.

It turned out that about $67 \%$ of respondents have "smart" gadgets. At the same time. the study showed that the level of rejection of the use of wearable gadgets reaches $27 \%$. This situation is explained by the fact that many consumers consider wearable devices simply insufficiently functional. In many cases. the capabilities of such products repeat the functions of smartphones.

The survey also revealed two more problems of modern wearable gadgets, $28 \%$ of users indicate their high cost and $39 \%$ of the unattractive design.

After completing a marketing analysis of smart watch products and fitness trackers. the following conclusions can be made. First, products are competitive and occupy a certain share of the electronics market.

Secondly. the product develops. creating all new products that allow to satisfy even the most loyal customers.

Thirdly, as we see, with its quality and simplicity of products, with the support and constant introduction of innovations. these products win the trust of a large audience of consumers. despite numerous consumer complaints.

In the coming years, and maybe even months, wearable gadgets will undergo many more changes for the better. Today, their functions are mainly focused on helping us to take care of ourselves and to be in touch - not only in our free time, but also in the workplace. According to Deloitte, by 2022 about 500 global corporations intend to introduce wearable technology into the workflow.

100 respondents took part in the survey. of which $51 \%$ of the respondents were female and $49 \%$ male. The age category was: $11 \%$ - up to $17.49 \%-$ from 18 to $30.27 \%$ - from 31 to $45.8 \%$ - from 46 to $60.5 \%$ - from 61 st and older.

The study showed that $71 \%$ of people out of 100 respondents know what the difference is between smart watches and fitness trackers. and only $29 \%$ of people said they do not know. To the question "What is the main reason for buying fitness trackers or smart watches?" $14 \%$ of people answered - loss. breakdown of the old, $20 \%$ of people - the emergence of a new. improved model. $13 \%$ of people - favorable discounts or promotions in the store to buy a new gadget $22 \%$ of people - fashion and style and $31 \%$ of people - is an essential helper, which simplifies life.

To the question "Where did you buy or purchase smart watches or fitness trackers?" $20 \%$ of the people answered - in an independent retail store, $31 \%$ of people in chain stores, $39 \%$ of people in online stores, $10 \%$ of people buy in others places.

When choosing smart watches or fitness trackers. consumers rely on these characteristics: $46 \%$ of people answered - quality. $17 \%$ of people - price. $16 \%$ of people - additional applications, $19 \%$ of OS people, $2 \%$ of people - another.

After analyzing the prices of smart watch 
products and fitness trackers for consumers, prices are so high that they refuse to buy: $9 \%$ of people are less than $1000 \mathrm{UAH}, 34 \%$ of people are from 1000 to $3000 \mathrm{UAH}, 23 \%$ of people are from 3000 to 5000 UAH, $19 \%$ of people - from 5.000 to $8.000 \mathrm{UAH}$, $15 \%$ of people - from $8.000 \mathrm{UAH}$ and above.

\section{Conclusions}

After conducting a marketing research in the form of a survey. we studied the consumers of this product. its features and preferences in this segment. And found that only $67 \%$ are users of these products, and even among these $67 \%$ there are $27 \%$ who are not satisfied with the product for technical, economic, geographical or other external reasons, that is, there is a demand for these goods, which allows you to open a business in this segment, but it is costly to meet the demand of each consumer.

After analyzing the macro environment, we can conclude that due to the instability of the economy and the political situation in our country, as well as problems among the population, opening a regular store will be an expensive undertaking that may not bring the expected income in a given period of time. Exploring the micro environment, we understand that there are a lot of competitors in this market segment, but they do not respond to all customer requests, for example, the ratio of quality and price. The main competitors are the AlliExpress and Rosetka marketplaces, as well as Allo and Citrus retail chains.

Based on the foregoing. we recommend:

1. To postpone the opening of the store, and start with the Internet site and gain a certain trust from customers in this market segment;

2 . To focus not only on the younger generation. but also to work on the demand for older people;

3. When buying a product in China, monitor the quality of the product in order to satisfy not only its financial needs, but also the demands of buyers.

\section{REFERENCES}

1. Cherchyll' H. Braun T. Marketynhovye yssledovanyia 5-e yzd / Per. s anhl. pod red. H. L. Bahyeva. - SPb.: Pyter. 2007.

2. Starostina A.O. Marketynhovi doslidzhennia natsional'nykh i mizhnarodnykh rynkiv: Pidruchnyk. - Kyiv: TOV «Lazaryt-Polihraf». - 2012.

\section{АНАЛІЗ СМАРТ-ГОДИННИКІВ ТА ФІТНЕС-ТРЕКЕРІВ НА РИНКУ УКРАЇНИ}

\section{Іщенко І., Савенко А., Чуприна Н., Ковальова М.}

У статті проаналізовано товари смарт-годинників фітнес-трекерів, з метою з'ясувати на скільки їх продукція. що випускається, є затребуваною на сучасному ринку, а також який магазин краще відкрити (онлайн або звичайний) $i$ чи вигідно відкривати магазин з товаром фітнес-трекерів і смартгодинників. Основна проблема з теми полягає в малому науковому дослідженні в даній сфері діяльності, відповідно стаття має узагальнений новий матеріал, який враховує всі аспекти реальної маркетингової ситуації. При вивченні смарт-годинників і фітнес-трекерів виконувався теоретичний огляд макромаркетингового і мікромаркетингового середовища. В результаті отриманих даних був сформований аналіз, в якому були враховані переваги і недоліки ринку смарт-годинників і фітнестрекерів. на основі відбору і аналізу факторів макромаркетингового середовища, а саме таких факторів як: політичні, економічні, демографічні, науково-технічні і соціально-культурні. Особливу увагу приділено дослідженню конкурентного середовища, де були розглянуті основні конкуренти підприємствапочатківия з продажу фітнес-трекерів і смарт-годинників, а саме такі торгові майданчики як «Ельдорадо», "Сотfу», «AliExpress», «Розетка», «Фокстрот», «Цитрус», «Алло». На основі вивчених даних був здійснений аналіз кількості моделей кожного наданого конкурента для визначення асортименту товару. Виконано аналіз постачальників, який спрямований на виявлення тих аспектів в діяльності суб'єктів, що постачають організацію різною сировиною, напівфабрикатами. енергією, інформацією. фінансами і та ін, від яких залежать ефективність роботи організації, собівартість і якість виробленого організацією продукту. У статті проаналізовано кожен продукт серед наданих конкурентів для розрахунку середньої ціни, щоб побачити різницю ціни продуктів, виготовлених в Китаї, країнах ЕС та США. Дані показники зумовлюють дії у виборі постачальників і посередників продукції. На основі вивчення конкурентоспроможності даного сегмента ринку була запропонована базова стратегія М. Портера яка передбачає спеціалізацію діяльності фірми на вузькому сегменті споживачів $і$ завоювання в иьому сегменті лідерства. Мета стратегії - задовольнити потреби обраного иільового сегмента краще, ніж конкуренти. Для визначення ставлення суспільства до галузі на даному сегменті ринку, було проведено опитування споживачів в якому взяли участь 100 респондентів з яких $51 \%$ опитаних - представники жсіночої статі і 49\% - чоловічої 3 метою з'ясувати які характеристики смарт-годинників $i$ фітнес-трекерів влаштовують або не влаштовують споживачів, а також проблеми сучасних носимих гаджетів. Інтегрувавши вивчену інформацію, визначена стійкість даного сегмента ринку і можливості для відкриття свого підприємства. Запропоновано рекомендації для відкриття магазину в сфері смарт-годинників і фітнес-трекерів.

Ключові слова: потенційний споживач, дослідження ринку, аналіз конкурентів, ціновий сегмент, конкурентна перевага. 


\section{АНАЛИЗ СМАРТ-ЧАСОВ И ФИТНЕС-ТРЕКЕРОВ НА РЫНКЕ УКРАИНЫ}

\section{Иценко И., Савенко А., Чуприна Н., Ковалева М.}

В статье проанализировано товары смарт-часов и фитнес-трекеров. с иелью выяснить на сколько их выпускаемая продукция является востребованной на современном рынке, а также какой магазин лучше открыть (онлайн или обычный) и выгодно ли открывать магазин с товаром фитнес-трекеров и смарт-часов. Основная проблема по теме заключается в малом научном исследовании в данной сфере деятельности. соответственно статья имеет обобщенный новый материал, который учитывает все аспекты реальной маркетинговой ситуации. При изучении смарт-часов и фитнес-трекеров проводился теоретический обзор макромаркетинговой и микромаркетинговой среды. В результате полученных данных был сформирован анализ, в котором были учтены преимущества и недостатки рынка смарт-часов и фитнес-трекеров, на основе отбора и анализа факторов макромаркетинговой среды, а именно таких факторов как: политические, экономические, демографические, научно-технические и социально-культурные. Особое внимание уделено исследованию конкурентной среды, где были рассмотрены основные конкуренты начинающего предприятия по продаже фитнес-трекеров и смарт-часов, а именно такие торговые площадки как «Эльдорадо», "Сотfу», «AliExpress», «Розетка», «Фокстрот», «Цитрус», «Алло». На основе изученных данных был проведен анализ количества моделей каждого представленного конкурента для определения ассортимента товара. Проведен анализ поставщиков, который направлен на выявление тех аспектов в деятельности субъектов, снабжающих организацию различным сырьем, полуфабрикатами, энергией, информацией, финансами и т.n., от которых зависят эффективность работы организации. себестоимость и качество производимого организацией продукта. В статье проанализирован каждый продукт среди представленных конкурентов для расчёта средней цены, чтобы увидеть разнииу цены продуктов, изготовленных в Китае, странах ЭС и США. Данные показатели предопределяют действия в выборе поставщиков и посредников продукции. На основе изучения конкурентоспособности данного сегмента рынка была предложена базовая стратегия М. Портера которая предусматривает специализацию деятельности фирмы на узком сегменте потребителей и завоевание в этом сегменте лидерства. Цель стратегии - удовлетворить потребности выбранного целевого сегмента лучше, чем конкуренты. Для определения отношение общества к отрасли на данном сегменте рынка, был проведен опрос потребителей в котором приняли участие 100 респондентов из которых $51 \%$ опрошенных - представители женского пола и 49\% - мужского с иелью выяснить какие характеристики смарт-часов и фитнес-трекеров устраивают или не устраивают потребителей, а также проблемы современных носимых гаджетов. Интегрировав изученную информацию, определена устойчивость данного сегмента рынка и возможности для открытия своего предприятия. Предложены рекомендации для открытия магазина в сфере смарт-часов и фитнес-трекеров.

Ключевые слова: потенциальный потребитель, исследование рынка, анализ конкурентов, ценовой сегмент, конкурентное преимущество.

\section{ANALYSIS OF SMART HOURS AND FITNESS TRACKERS IN THE MARKET OF UKRAINE}

Ishchenko I., Savenko A., Chupryna N. *, Kovalova M. Ukrainian State University of Chemical Technology, Dnipro, Ukraine

\section{* e-mail: chupryna_n_n@ukr.net}

The article analyzed the goods of smart watches and fitness trackers, in order to find out how much their manufactured products are in demand in the modern market, as well as which store is better to open (online or regular) and whether it is profitable to open a store with a product of fitness trackers and smart hours The main problem on the topic is a small scientific research in this field of activity, respectively, the article has a generalized new material that takes into account all aspects of the real marketing situation. When studying smart watches and fitness trackers, a theoretical review of macromarketing and micromarketing environments was conducted. As a result of the obtained data, an analysis was formed, which took into account the advantages and disadvantages of the smart watch market and fitness trackers, based on the selection and analysis of factors of the macro-marketing environment, namely such factors as political, economic, demographic, scientific and technical, and sociocultural. Particular attention is paid to the study of the competitive environment, where they considered the main competitors of the start-up enterprise selling fitness trackers and smart watches, namely, such trading platforms as Eldorado, Comfy, AliExpress, Rosette, Foxtrot, «Citrus», «Allo». On the basis of the data studied, an analysis was made of the number of models of each competitor presented to determine the product range. The analysis of suppliers, which is aimed at identifying those aspects in the activities of entities supplying the organization with various raw materials, semi-finished products, energy, information, finance, etc., on which the effectiveness of the organization, cost and quality of the product produced by the organization depends, is carried out. The article analyzes each product among the submitted competitors to calculate the average price in order to see the difference in the prices of products manufactured in China, EU countries and the USA. These indicators predetermine actions in the selection of suppliers and intermediaries of products. Based on the study of the competitiveness of this market segment, the basic strategy of $M$. Porter was proposed, which provides for the specialization of the company's activities in a narrow segment of consumers and gaining leadership in this segment. The goal of the strategy is to satisfy the needs of the chosen target segment better than the competitors. To determine the attitude of society to the industry in this market segment, a consumer survey was conducted in which 100 respondents took part, of which $51 \%$ of respondents are female and $49 \%$ are male in order to find out which characteristics of smart watches and fitness trackers suit or not satisfied with consumers, as well as the problems of modern wearable gadgets. By integrating the information studied, the stability of this market segment and the possibilities for opening your business are determined. Suggested recommendations for opening a store in the field of smart watches and fitness trackers.

Keywords: potential consumer, market research, analysis of competitors, price segment, competitive edge.

\section{REFERENCES}

1. Cherchyll' H., Braun T. (2007). Marketynhovye yssledovanyia 5-e yzd. / Per. s anhl. pod red. H. L. Bahyeva. - SPb.: Pyter [in Russian].

2. Starostina A.O. (2012). Marketynhovi doslidzhennia natsional'nykh i mizhnarodnykh rynkiv: Pidruchnyk. - Kyiv: TOV «Lazaryt-Polihraf» [in Ukraine]. 